\title{
Digital Backchannel: Promoting Students' Engagement in EFL Large Class
}

\author{
https://doi.org/10.3991/ijet.v14i07.9128
}

\author{
Siti Yulidhar Harunasari ( $\left.{ }^{\varpi}\right)$, Nurhasanah Halim \\ School of Education, STKIP Kusuma Negara, Jakarta, Indonesia \\ yulidhar1@stkipkusumanegara.ac.id
}

\begin{abstract}
Students' engagement is generally believed to be the independent predictor signifying the continuous existence of learning process. It is generally reflected in active participation such as listening to presentation, expressing opinions, asking questions, and working on assignment. However, the idea of being embarrassed in front of peers and the feeling of being reluctant to disturb others can often be intimidating for many students and might prevent them to ask questions during class discussion. As a result, meaningful discussion that is expected to happen during the lesson oftentimes takes another form of side conversation such as whispering, note passing, and text messaging, the so-called backchanneling. In addition to this, the class size has also been generating another issue. The larger the class is, the greater challenges the teachers face to engage students in their learning. To address this issue, this research investigates how a digital backchannel chat platform promotes students' engagement in an Indonesian EFL large class and transfers the side conversation to the forefront. A number of 41 college students took part in this single-case study approach. The research data were taken from interviews, classroom observations, and students' task submission. The degree of students' engagement was measured in 3 types of engagement, i.e. emotional, behavioral and cognitive engagement. Research findings suggested that the digital backchannel promoted students engagement with the learning activity, and enabled lecturers to provide immediate feedback on the students understanding over the lesson material in a large class.
\end{abstract}

Keywords—Students'engagement, digital backchannel, large class

\section{Introduction}

Students' engagement is widely recognized as important in the learning process. It is reflected mainly in active participation such as listening to presentation, expressing opinions, asking questions, and working on assignment. However, the idea of being embarrassed in front of peers and the feeling of being reluctant to annoy their peers can often be intimidating for many students, and might even prevent them to ask questions during class discussion. As a result, meaningful discussion that is expected to happen during the lesson oftentimes takes another form of side conversation such as whispering, note passing and text messaging, the so-called backchanneling. It has 
become actual challenges for most lecturers, especially in large classes, to motivate and engage students in their learning. In fact, the larger the class is, the greater challenges the teachers are going to face. The first challenge is that it is common in large classes that only a small percentage of students are identified as being active in classroom discussions. There are few students participating in the discussion, other students hesitantly decide to take the opportunities because of their slower pace to develop ideas, and the rest remain passive. The second challenge is to promote students' engagement in which teacher needs to know "where their students are in their understanding" and "what questions to ask to make the learning process occur", and this is certainly no less important. The last but not least is lecturers need not only to select meaningful learning activities but also useful tools and valuable resources to motivate and engage their students in the learning process.

Information and Communication Technology (ICT)-Pedagogies integration is potential not only to promote but also to transfer learning [1]. This claim supports findings that increasing students' motivation and engagement was one of the three major contributions brought by the (ICT)-Pedagogies integration to learning, and the integration has a direct positive relationship with students' engagement and self-directed learning [2-6]. Llorens et al. (2007) as stated in [7] also found evidence that learners' belief in their sufficient resources leads to the increase of self-efficacy, which leads to learners engagement's increase, which then spirals up to gain greater self-beliefs.

Moreover, of the 26 relevant research found in the Web, recent research on ICT in education emphasized the needs of teaching and learning using technology for teacher educators [8] and can be considered as a positive reinforcement to a research finding within Indonesia context. It was found in the research that the majority of teachers feel comfortable using ICT as a tool for teaching and learning, and they agree that using ICT is fascinating and interesting [9]. This is also in agreement with the claim that students felt positive about technology in the classroom and its use has a direct positive relationship with students' engagement [5] [10]. In teaching English as Foreign Language (EFL) context, a recent evidence also suggests that by embedding ICT into classes, students with lower interest and less intrinsic motivation will get a greater level of comfort and a higher degree of engagement during their task performances [11-13]. However, the two studies were conducted in considerably small classes. A question then was raised. i.e., when the ICT has been integrated, how to promote students' engagement in a large class considering that in large classes the communication between students and lecturers could be complicated? [10]

Large classes, in many situations, seemed to bring problems instead of challenges in the process of teaching and learning. Such problems as the quality of teacherstudent interactions, the effectiveness of teaching, teacher's effort in fostering students' attentiveness are questionable. In addition to this, in a large class, even the classroom seating arrangement should be a problem as well. Wannarka and Ruhl (2008) stated in [14] believed that teachers' decision in seating arrangements could result in the improvement of students' engagement and development. In short, $\mathrm{Xu}$ (2001) concluded that most English teachers tend to have a negative view on teaching English in large classes. He puts forward that when teaching in large classes, the 
teacher has to deal with not only physical problem but also psychological and technical problem [15].

How large is a "large class"? Then might be the next question to ask. To answer the question, there are certain characteristics to define a large class that need to be attended. Hess and Ur in [16] claimed that the number of students in a large class would be around 30, but does not exceed 50 students. However, Ur (1996) as stated in [17] also suggested that "the exact number does not really matter: what matters is how you, the teacher see the class size in your own specific situation". A different thought was put forward on the size of a large when they say: "A large class can be any number of students if the teacher feels there are too many students for them all to make progress" [18]. Therefore, what labeled a 'large class' is context-dependent. Taken together, from what have been discussed, there is no exact number can be used to define the "large" as there are no certain characteristics that can be taken into account to consider whether or not a class is large. However, whatever it is, either the size of the class or the number of students accommodated in affects the way teachers cope with it. For this reason, lecturers need to be aware in adopting resources and techniques to the needs of their class.

\subsection{Students' engagement}

Students' engagement is a "psychological investment" in learning and the efforts put into the enhanced engagement takes form of active involvement, commitment, and concentrated attention [19]. It implies that an engaged student feels as if she or he is part of the learning process. Engagement could take form in various kinds such as paying attention to lecturer's or peer's presentation, expressing opinions, asking questions, and working on assignment. Due to its importance, Tinto and Kuh (2003) in [20] [21] claimed engagement as the single most significant predictor of persistence and lead to students success and development. Researches have also shown that there were significant relationships between the students' academic achievement and students' engagement, and that engagement leads to better grade [20] [22].

In a broader context, student engagement is articulated as the active involvement of listening to individual and collective perspectives of students, about matters, which relate to the students' experiences of higher education, which aimed to promote the students learning and experience in higher education institutions [23]. However, these forms of active involvement can often be intimidating for many students. The idea of being embarrassed in front of peers and the feeling of being reluctant to annoy their peers might prevent them to ask questions during class discussion. It is claimed that such problems are very typical in many universities these days [11]. This, of course, has also been a challenge to the lecturers of STKIP Kusuma Negara, a private school of education for pre-service teachers located in Jakarta, Indonesia, which is the research context for the present study.

Previous researches on EFL have reported that studies on lectures, with their roles as events, were conducted not only to determine what has been considered the facilitators in student comprehension but also to examine how to give the most benefits of these events to the linguistic and communicative competence of second and foreign 
language students [24]. Wesch and Ready (1985) as stated in [25] found that gains in second language proficiency are best achieved in situations where the second language is used as a vehicle for communication about other subjects rather than itself. It was also implied from other studies of lectures in non-English speaking countries that most interactive lectures will be beneficial not only for the sake of students' comprehension but also for the improvement of students' linguistic and communicative competence [12] [24] [26]. It means lecturers must look for ways in involving their students to actively take parts in the lectures. On the other hand, to address this challenge, Social Constructivism offers a foundation to learners to actively create meaning when interacting with another, and impact greatly on online educational practice especially where the aims of instruction are broader than can be easily accounted within traditional approaches [27]. For this reason, backchanneling is worthy of being considered a medium through which certain types of learning activity can take place to promote students' engagement.

Measuring students' engagement could be done in three psychological levels. "First, students' engagement with material which is primarily cognitive in nature, or with learning, The next level is students' engagement with groups or community which is social in nature; and the last is students' engagement with schooling which might be considered sociological or anthropological in nature, that all should be well thought-out to promote learning" [28] [29]. The first level was the focus of the study. In line with the aforementioned, Fredricks, Blumenfeld, \& Paris (2004) in [30] described and assessed students' engagement in three distinct types of engagement: behavioral, cognitive and emotional. These were explained as follows. [30] "Behavioral engagement involves: positive conduct, e.g., adhering to classroom norms, the absence of non-disruptive behaviors; involvement in learning tasks, e.g., effort, persistence; and participation in school-related activities, e.g., athletics, governance. These behaviors which may be academic or nonacademic assess the extent to which students are actively participating in relevant learning tasks presented. Emotional engagement involves affective reactions in the classroom, e.g., interest, happiness; affective reactions to the teacher, e.g., liking, respecting; and identification with school, e.g., belonging and valuing which sometimes intersects with constructs used in motivational research. These criteria assess the level of students' investment in, and emotional reactions to the learning tasks. Cognitive engagement comprises psychological investment in learning, e.g., desire to go further than the requirements, preference for a challenge; inner psychological investment, e.g., desire to learn, desire to master skills; and self-regulation, e.g., use of metacognitive strategies, evaluating cognition when completing tasks." Cognitive criteria determine the extent to which students are expending mental effort in the learning tasks [31].

There are also several considerations to be taken in measuring student engagement. Firstly, teachers should view engagement as a multidimensional construct uniting the three components. It is also vital that the teacher plan should include at least one indicator from each of the three engagement components behavioral, emotional and cognitive [29] [30]. Secondly, teachers should choose relevant indicators aligned with the learning outcomes. The number of indicators should reflect the purpose and the extent of the learning activity at which the students' engagement is being measured. Thirdly, 
the method of measurement should be reliable for each indicator. More than one form of self-reporting, teacher-reporting and observational methods of measurement should be used. Lastly, teachers should remember that the level of engagement of a student may vary during the learning activity and so measurement of indicators should not be timing-dependent.

To help teachers develop their plan to measure student engagement, it was proposed in [29] an example of Engagement Measurement Plan which was used when students were involved in a learning task integrating the use of Multimedia. The plan comprises of types of engagement, the indicators of each component, and the measurement methods. In line with the purpose of the present study and the example of the plan, two indicators were developed to measure behavioral and cognitive engagement, and one indicator was developed for emotional engagement so that it can be observed via digital backchannel and a Learning Management System, which were employed to support students' learning.

\subsection{Digital backchannel}

Preceding the internet chat room context, Yngve (1970) in [3] defined backchannel as conversational devices used by listeners to signal engagement. At present, the advance of technology has empowered teachers to make use digital backchannels, defined as "online interaction spaces that run parallel to spoken remarks" in [32], to engage their students with their learning. Several studies, interestingly, have revealed that digital backchannels offered students a sense of engagement and make them feel more sociable. It also offered students opportunities to participate more in class discussion. It was found that the low-performing students could be excelled to be active participants in the backchannel discussion. Through digital backchannel, all students would make positive experiences toward the learning process, especially in crafting their thoughts deliberately. As stated in [32] the backchannel tools made these possible because of the "public anonymity/private accountability options". It appeared that students who felt less competent than others were encouraged to take the challenge of expressing their opinions aloud in the backchannel discussion because of the supporting features. It was remarkable that the feature would allow a particular student to express their opinion, to share ideas, to ask questions, etc., unidentified by his/ her peers during the discussion, yet the lecturer could still have his/ her name on the screen.

Not only facilitating students' voice, backchannel tools also benefited students from questions posed by others [36]. It also assists teachers in formative assessment of students' understanding as well help teachers to timely response to students' questions. Furthermore, it offers opportunity for teachers to monitor the dynamics of the group to be studied and improved for future classes [6] [34] [36]. Backchannels can be introduced using a variety of Web-based or social media and microblogging platforms, including Facebook, Twitter, and Edmodo, which require user accounts. However, other services, such as TodaysMeet do not require account-creation and can be utilized by instructors with ease [3] [36]. Students can easily join and start rooms with no registration, and immediately start conversations that augment the traditional class- 
room. It is specially designed for teachers and takes great care to respect the needs and privacy of students while giving educators the tools to support learning. For example, to join a TodaysMeet chat room is as simple as visiting a web page. Students can enter the chat room by typing the room's address into their browsers, copying the URL shared by teacher, or just scanning the QR codes to help students with phones or tablets join without typing the URL. These ways are mostly applicable to similar services offering the backchannel. This research used TodaysMeet as its backchannel for its free service and user-friendly. It is also so unfortunate that TodaysMeet has been shut down by his own creator in June 2018, a year upon the completion of this study. However, there are several replacements offering the same features to such as Backchannel Chat, GoSoapBox, Mentimeter, Pear Deck, etc.

\subsection{Research questions (RQs)}

To address the challenge on how to promote students' engagement, two research questions were raised.

- RQ1 : Can digital backchannel promote students' engagement in the learning process in a large class?

- RQ2 : If so, can digital backchannel help lecturer to know students' understanding over the lesson material?

\section{Methods}

\subsection{Study participants and settings}

This single-case study took place in a natural setting and involved 41 college students. They were 5 male students and 36 female students attending "ICT in English Language Teaching", a subject course for the semester 6-students with its main aim to introduce students to the key concepts of English language teaching methodologies and the use of new technologies. The principal working language of the course is English.

In order to determine how backchannel influenced students' engagement in the learning session which consisted of 14 meetings were divided into two parts. The first half was dedicated to lecture-mode sessions, while the other half, 7 meetings in total, were sessions in which TodaysMeet was used as a backchannel chat platform to support the lectures. Every session began with a lecture to introduce the basic concepts and was followed by group presentation and class discussion on the assigned readings. The TodaysMeet was introduced in the $7^{\text {th }}$ meeting at which the topic was "Using chat in teaching English". As a matter of fact, this was also the $7^{\text {th }}$ topic to be covered in the course. 


\subsection{Procedures in collecting data}

This study used a mixed-method approach. To give a more valid and reliable view of engagement, the measurement should include more than one perspective on the engagement. To this end, the Engagement Measurement Plan proposed by Chris Reading in [29] was adapted to collect data in this study:

- Classroom observations,

- Students' task submission in Edmodo LMS at https://www.edmodo.com/home\#l group?id $=21237523$

- A semi-structured online interview to students. To support the observations and interview, any data considered useful for the research was recorded as field notes.

The behavioral engagement component was measured using observation techniques, i.e. classroom observation and students task submission recorded within Edmodo Learning Management System.

The emotional engagement was visualized through a semi-structured online interview where the students' perspectives were gathered through open questions. Through this, students were allowed to reflect on their own experience and to report on what they believed or what they remembered had promoted engagement in their classroom.

The cognitive engagement was measured through students' responses in the backchannel using observation technique.

To sum, the types of engagement along with indicators which were measured, the methods of measurement, and the sources of data are presented at the following table (see Table 1).

Table 1. Summary of students engagement measurement method and data source(s)

\begin{tabular}{|c|c|c|c|}
\hline Type & Indicators & $\begin{array}{l}\text { Measurement } \\
\text { Method }\end{array}$ & $\begin{array}{c}\text { Data } \\
\text { Source(s) }\end{array}$ \\
\hline \multicolumn{4}{|l|}{ Behavioral } \\
\hline - Conduct & $\begin{array}{l}\begin{array}{l}\text { Numbers of the } \\
\text { question } \\
\text { asked } \\
\text { through } \\
\text { backchannel. }\end{array} \\
\end{array}$ & Observation & $\begin{array}{l}\text { Digital } \\
\text { Backchannel }\end{array}$ \\
\hline $\begin{array}{l}\text { - Work } \\
\text { involvement }\end{array}$ & $\begin{array}{l}\text { On-time task } \\
\text { submission }\end{array}$ & Observation & $\begin{array}{l}\text { LMS } \\
\text { (Edmodo) }\end{array}$ \\
\hline \multicolumn{4}{|l|}{ Emotional } \\
\hline $\begin{array}{l}\text { - Affective } \\
\text { Reactions }\end{array}$ & $\begin{array}{l}\text { Enthusiasm for using } \\
\text { digital backchannel }\end{array}$ & $\begin{array}{l}\text { Semi-structured } \\
\text { online interview }\end{array}$ & $\begin{array}{l}\text { Digital } \\
\text { Backchannel/ } \\
?\end{array}$ \\
\hline \multicolumn{4}{|l|}{ Cognitive } \\
\hline \multirow[t]{2}{*}{$\begin{array}{l}\text { Instructional } \\
\text { discourse }\end{array}$} & $\begin{array}{ll}- & \text { Posing } \\
& \text { questions }\end{array}$ & Observation & $\begin{array}{l}\text { Digital } \\
\text { Backchannel }\end{array}$ \\
\hline & $\begin{array}{l}\text { - Response to } \\
\text { lecturer's } \\
\text { question. }\end{array}$ & Observation & $\begin{array}{l}\text { Digital } \\
\text { Backchannel }\end{array}$ \\
\hline
\end{tabular}




\subsection{Data analysis}

A combination of quantitative and qualitative approaches was used in the data analysis. The quantitative data comprised of numbers were analyzed based on descriptive statistics and frequency distributions, while the qualitative data comprised of students responses were analyzed through data description, data display and verification.

\section{$3 \quad$ Findings}

\subsection{Digital backchannel promoted students engagement}

Behavioral Engagement: Based on the classroom observation, the frequencies of questions posed in the backchannel sessions was five times greater than the lecture mode sessions. The average frequencies of the students asking questions during the backchannel discussion was $32.95 \%$, comparing to only $5.97 \%$ of the students during the lecture session. It means that during the whole sessions in the research, there were at least 14 students who were fully engaged with the materials discussed in each backchannel session. This evidence was over researchers' expectation (see Table 2 for details). It is also a supporting evidence that digital backchannel can increase students' engagement. On the contrary, there were still 27 students who did not ask questions. However, they might not be considered passive, because they might be in their efforts to get used to the online interaction during class.

Table 2. Frequencies of students' questions

\begin{tabular}{|c|c|c|c|c|c|c|c|c|c|c|c|c|c|c|}
\hline & \multicolumn{7}{|c|}{ Lecture Mode } & \multicolumn{7}{|c|}{ Digital Backchannel-Supported Mode } \\
\hline Sessions & 1 & 2 & 3 & 4 & 5 & 6 & 7 & 8 & 9 & 10 & 11 & 12 & 13 & 14 \\
\hline $\mathbf{n}$ & 41 & 41 & 40 & 37 & 41 & 40 & 39 & 39 & 41 & 41 & 40 & 36 & 41 & 41 \\
\hline Frequencies & 3 & 2 & 2 & 4 & 3 & 1 & 2 & 7 & 14 & 13 & 21 & 13 & 9 & 15 \\
\hline Percentage & $7.3 \%$ & $4.8 \%$ & 4.806 & $10 \%$ & $7.3 \%$ & $2.50^{\circ}$ & $5.1 \%$ & $17.90 \%$ & $34.1 \%$ & $31.7 \%$ & $52.5 \%$ & $36.1 \%$ & $21.9 \%$ & $36.5 \%$ \\
\hline Average & \multicolumn{7}{|c|}{$5.97 \%$} & \multicolumn{7}{|c|}{$32.95 \%$} \\
\hline
\end{tabular}

Another behavior indicating students' engagement is submitting the task on time. It was found that the frequencies of students' task-submission in lecture session and backchannel session was slightly different. This was unexpected as the previous behaviour (students' frequencies of asking questions) was greatly increased. Edmodo Learning Management System recorded that $90.4 \%$ students (in average) submitted their task on time in each session. While in the lecture session, there were $89 \%$ of 
students (in average) submitted on-time. The comparisons of the two different mode sessions can be seen in the following table (see Table 3 ).

Table 3. Frequencies of students' task submission

\begin{tabular}{|c|c|c|c|c|c|c|c|c|c|c|}
\hline \multicolumn{6}{|c|}{ Lecture Mode } & \multicolumn{5}{|c|}{ Digital Backchannel-Supported Mode } \\
\hline Assignment & 1 & 2 & 3 & 4 & 5 & 1 & 2 & 3 & 4 & 5 \\
\hline Frequencies & 40 & 36 & 34 & 36 & 36 & 36 & 36 & 41 & 36 & 36 \\
\hline Percentage & $98 \%$ & $88 \%$ & $83 \%$ & $88 \%$ & $88 \%$ & $88 \%$ & $88 \%$ & $100 \%$ & $88 \%$ & $88 \%$ \\
\hline Average & \multicolumn{5}{|c|}{$89 \%$} & \multicolumn{5}{|c|}{$90.4 \%$} \\
\hline
\end{tabular}

The visualization of students' frequencies in task submission for the two different sessions is illustrated in Figure 1.

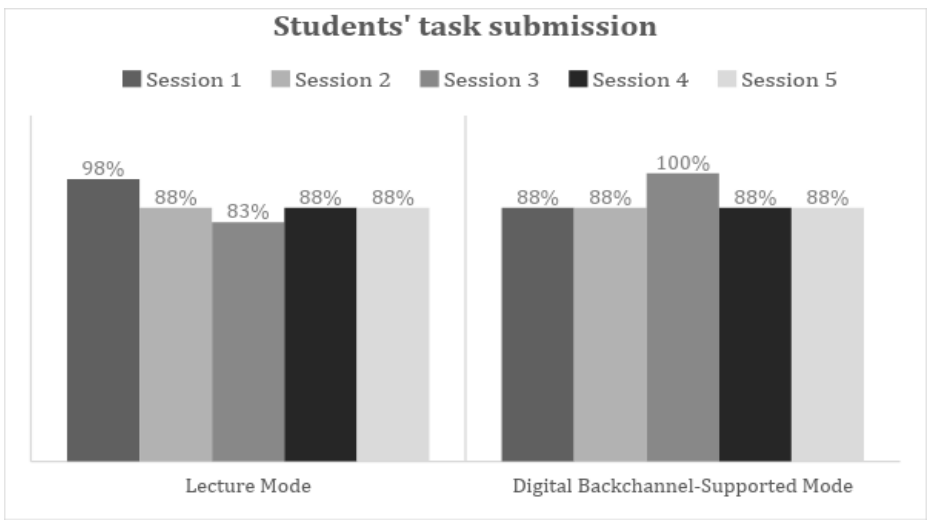

Fig. 1. Visualization of students' frequencies in task submission

Although the average frequencies were slightly different, students' engagement with the material was quite enhanced in the digital backchannel. It was based on the visualization, the bars' height happened to be more stable in the digital-backchannel session. The highest bar had even reached $100 \%$, meaning all the students were actively engaged with materials by submitting the task on-time. On the other hand, the lecture session was satisfactory as well. But, once the bar's height was only $83 \%$. This should be an input to improve students' engagement in the frontchannel.

During the submission time, it is important also to consider the external factor that might have a direct impact on students' failure in submitting task on-time. At the end of the digital backchannel session, the researcher found that a few students experi- 
enced the poorly performing internet connection so that they failed to submit the task on-time. This could be the major factor for the slight increase in students' engagement through digital backchannel.

Emotional Engagement: Students' emotional engagement was reflected in their response which was recorded in the digital backchannel.

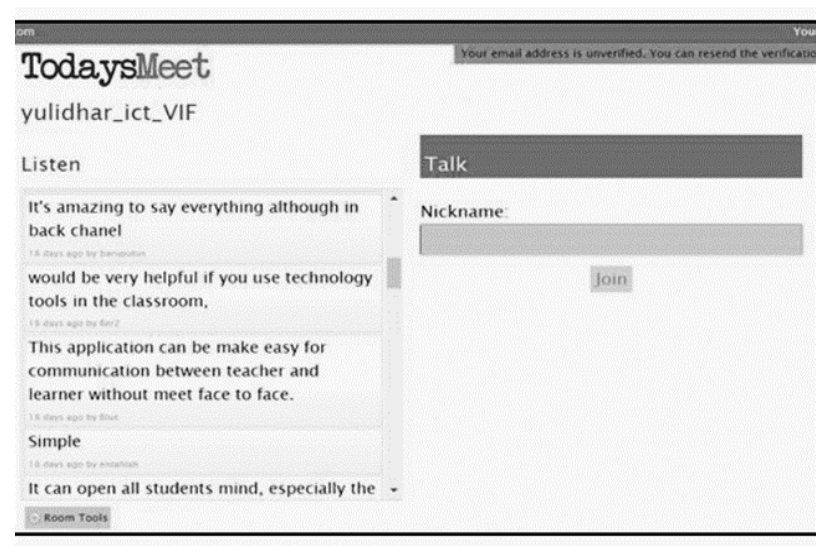

Fig. 2. Students' responses within Backchannel

The students' responses were coded as either:

- Positive response

- Neutral responses

- Negative responses

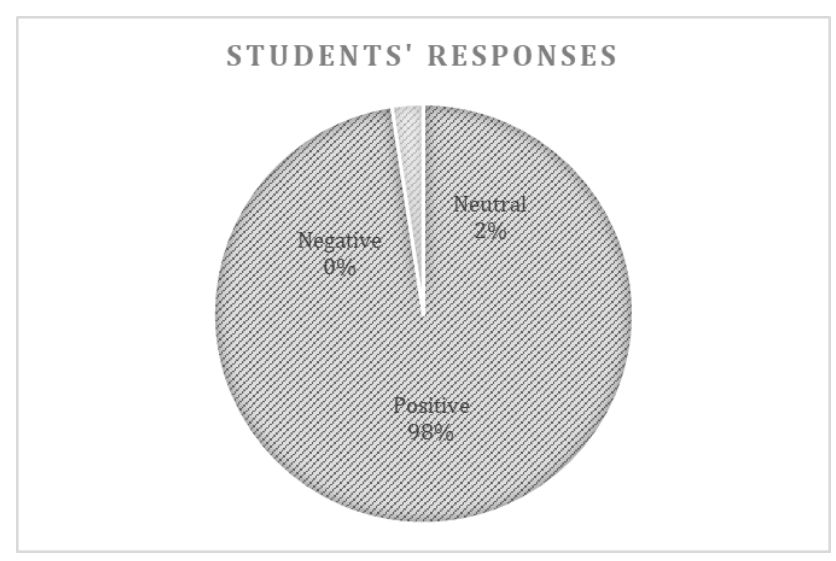

Fig. 3. Visualization of students' responses to Backchannel

Overall, students' responses were positive affective reactions to the learning experiences during the backchannel session. It was indicated that $97.6 \%$ of students (equals to 40 students) supported the use of digital backchannel in the learning pro- 
cess. Only one student, out of 41 respondents in the backchannel session, responded neutrally by typing "simple". See Figure 3 for details.

Cognitive Engagement: Students' posing topic-relevant questions was considered as one indicator of cognitive engagement.

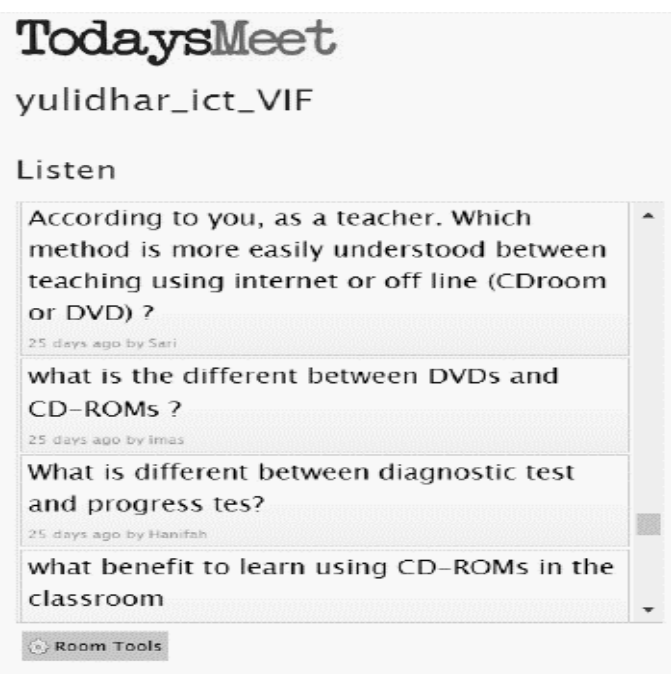

Fig. 4. Screen-shot of students' topic-relevant questions recorded in Backchannel

For the frequencies of the relevant questions posed by students can be seen in Table 4 .

Table 4. Frequencies of Topic-Relevant Questions Students Posed

\begin{tabular}{|c|c|c|c|}
\hline Meeting & $\begin{array}{c}\text { Number of } \\
\text { Questions }\end{array}$ & $\begin{array}{c}\text { Number of } \\
\text { Relevant } \\
\text { Questions }\end{array}$ & Percentage \\
\hline $8^{\text {th }}$ & 7 & 7 & $100 \%$ \\
\hline $9^{\text {th }}$ & 14 & 13 & $92 \%$ \\
\hline $10^{\text {th }}$ & 13 & 13 & $100 \%$ \\
\hline $11^{\text {th }}$ & 21 & 17 & $80 \%$ \\
\hline $12^{\text {th }}$ & 13 & 13 & $100 \%$ \\
\hline $13^{\text {th }}$ & 9 & 9 & $100 \%$ \\
\hline $14^{\text {th }}$ & 15 & 15 & $100 \%$ \\
\hline \multicolumn{4}{|c|}{ Average } \\
\hline
\end{tabular}


Disregarding the relevance of questions posed, it was obvious that there were always questions asked during the digital backchannel session. Whereas when topic relevance was considered, $96 \%$ of students in average asked relevant questions to the topic being discussed during the digital backchannel-supported mode. This means students had invested their desire to learn through backhannel discussion.

Students' Response Showed Better Understanding of the Material: In the $13^{\text {th }}$ meeting, a quiz on e-learning was prepared for the students using digital backchannel. Figure 5 provides a screen-capture of students' responses to the quiz.

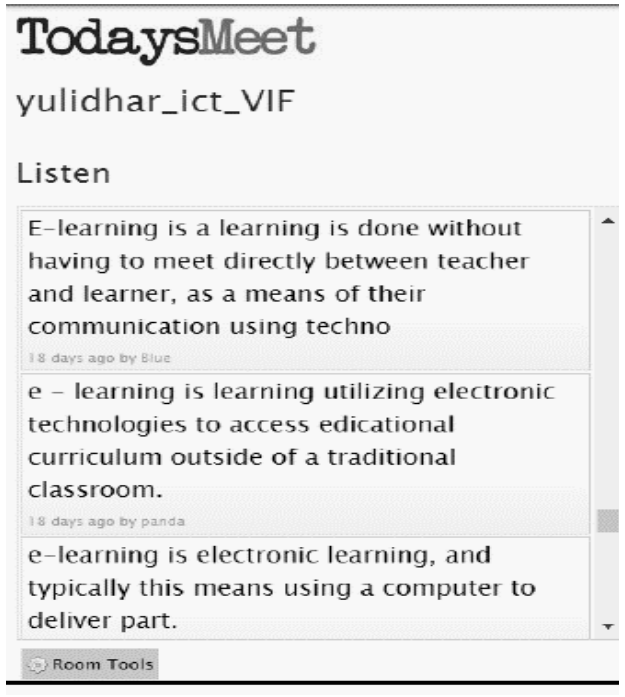

Fig. 5. Screenshot of students' responses on a quiz

Of 37 students responded to question, "What is e-learning?" 34 students showed a good understanding of the material. While 3 of them only gave very short responses such as "technology", "electronic learning" and "everything related to the internet."

\section{Discussion}

Based on the findings, it was obvious that a large class was neither a problem nor a challenge for a lecturer when the digital backchannel was utilized. Moreover, during the backchannel session, it was found that students' engagement was mostly promoted in the basis of the indicators assessed. Of the three engagement types measured, behavioral engagement was promoted extendedly. This was shown in students' effort to actively participate in class discussions and to submit the task on-time. "It is students' nature to primarily engage with the learning material" [28\} which was enhanced. Their efforts were the reflection of Alderman's statement in [28] that students' engagement promoted in line with the increase of students' confidence to self-control their own learning. Students' failure in submitting task on-time should be considered 
input for subsequent comprehensible research. Carpenter [32] took this as one of the challenges foreseen in the utilization of digital backchannel, other than distraction and quality.

From the emotional engagement's indicator, it was found that students' enthusiasm to use the digital backchannel was relatively stable. Students' engagement was promoted indicated by the increase in students' sense of belonging and valuing the learning process shown, i.e., their positive responses in the online interview. These were also the resemblance of students' positive affective reaction toward the utilization of digital backchannel in class. As a consequence, it is much easier for lecturers to improve students' proficiency in a language, and it is much easier for students to achieve their proficiency through a vehicle, the digital backchannel [3].

Students' frequencies of asking questions and students' asking relevant questions were promoted during digital backchannel session. Disregarding the relevance of the questions posed, it was obvious that there were always questions asked during the digital backchannel session. The desire to ask questions during the session should be considered as students' strategy to expand their knowledge by mastering the materials discussed. Whereas when topic relevance was considered, almost all students asked relevant questions to the topic being discussed during the digital backchannelsupported mode. This means students had invested their desire to learn through backhannel discussion. Based on these facts, students' cognitive engagement was greatly promoted by utilizing the digital backchannel.

\section{Conclusion}

The intended aim of this study was to reveal digital backchannel can promote students engagement in EFL large classes. The combination of quantitative and qualitative data analysis had confirmed that digital backchannel had made students engage during lectures and class discussions. It was obtained from the study that digital backchannel offered students a sense of engagement and that students also felt more positive about classroom discussions and that use of technology has a direct positive relationship with students' engagement and self-directed learning. The results also suggested that appropriate technology could be a useful tool to facilitate the development of an active learning environment. Returning to the questions raised at the beginning of this study, it is now possible to state that communication between students and lecturers should never be complicated in the so-called "large classes" when the digital backchannel was utilized. As a result, a large class will neither be a problem nor a challenge for a lecturer. Utilizing digital backchannel should also enable lecturers to provide immediate feedback on the students' understanding over the lesson material in a large class. 


\section{$5 \quad$ References}

[1] Ministerial Council on Education, Employment, T. and Y. A. (MCEETYA). Pedagogy Strategy: Learning in an Online World, 2003 Carlton South, http://hdl.voced.edu.au/10707 $/ 123527$

[2] Higgins, S. Does ICT Improve Learning And Teaching In Schools? A Professional User Review of UK research undertaken for the British Educational Research Association. Newcastle, 2003.

[3] Kassner, L. D., \& Cassada, K. M, “Chat It Up: Backchanneling to Promote Reflective Practice Among In-Service Teachers," Journal of Digital Learning in Teacher Education, 33(4), pp. 160-168, August 2017. https://doi.org/10.1080/21532974.2017.1357512

[4] Mueller, D. N, "Digital Underlife in the Networked Writing Classroom," Computers and Composition, vol 26, pp. 240-250, 2009. https://doi.org/10.1016/j.compcom.2009. 08.001

[5] Rashid, T., \& Asghar, H. M, "Technology Use, Self-Directed Learning, Student Engagement And Academic Performance: Examining The Interrelations," Computers in Human Behavior, vol. 63, pp. 604-612, October 2016. https://doi.org/10.1016/j.chb.2016. 05.084

[6] Yardi, S. Whispers in the Classroom, Innovation, and the Unexpected. (Tara McPherson, Ed.). The MIT Press, 2008. https://doi.org/10.1162/dmal.9780262633598.143

[7] Kahu, E. R, "Framing Student Engagement in Higher Education," Studies in Higher Education, volume 38, issue 5, pp. 758-773, August 2013. https://doi.org/10.1080/ 03075079.2011 .598505$.

[8] Uerz, D., Volman, M., \& Kral, M, “Teacher Educators' Competences in Fostering Student Teachers' Proficiency In Teaching And Learning With Technology: An Overview Of Relevant Research Literature. Teaching and Teacher Education, volume 70, pp 12-23, January 2018. https://doi.org/10.1016/j.tate.2017.11.005

[9] Safitry, T. S., Mantoro, T., Ayu, M. A., Mayumi, I., Dewanti, R., \& Azmeela, S, "Teachers' Perspectives and Practices in Applying Technology to Enhance Learning in the Classroom." International Journal of Emerging Technologies in Learning, 10 (3), pp.10-14. 2015. https://doi.org/10.3991/ijet.v10i3.4356

[10] Glessmer, \& Göttsch, P. Enabling Backchannel Communication Between A Lecturer and A Large Group. In SEFI 2014, 42nd Annual Conference.

[11] Baron, D., Bestbier, A., Case, J. M., \& Collier-Reed, B. I., "Investigating the Effects of A Backchannel on University Classroom Interactions: A Mixed-Method Case Study," Computers and Education, vol. 94 issue C, pp. 61-76, March 2016, https://doi.org/10.1016 /j.compedu.2015.11.007

[12] Harunasari, S. Y., \& Rahmat, A., "CALL-Based Instruction Model Of Speaking English (A Developmental Research at the English Language Education Study Program of STKIP Kusuma Negara, Jakarta)," International Journal of Language Education and Culture Review, 1(1), pp. 55-64, June 2015. https://doi.org/10.21009/IJLECR.011.07

[13] Purnawarman, P., Susilawati, S., \& Sundayana, W., "The Use of Edmodo in Teaching Writing in A Blended Learning Setting," Indonesian Journal of Applied Linguistics. Vol 5 No.2, 2016. https://doi.org/10.17509/ijal.v5i2.1348

[14] Gremmen, Mariola C, Yvonne H. M. van den Berg, Eliane Segers, \& Antonius H. N. Cillessen, "Considerations For Classroom Seating Arrangements and The Role Of Teacher Characteristics and Beliefs", Social Psychology of Education, December 2016. https://doi.org/10.1007/s11218-016-9353-

[15] Azizinezhad, M., Hashemi, M., \& Darvishi, S., "Relationship Between EFL Teachers' Attitudes, Teaching Techniques and Classroom (Large and Small)," Procedia - Social and 
Behavioral Sciences, vol 93, pp. 134-137, 2013. https://doi.org/10.1016/j.sbspro.2013.09. $\underline{165}$

[16] Treko, N. "The Big Challenge: Teaching Large Multi-Level Classes. Academic Journal of Interdisciplinary Studies," vol.2 (4), pp. 243-251, 2013. https://doi.org/10.5901/ajis. 2012.v2n4p243

[17] Renaud, Susan, Elizabeth Tannenbaum, \& Phillip Stantial, "Student-Centered Teaching in Large Classes with Limited Resources," English Teaching Forum, No. 3, pp. 24-34, 2007.

[18] Baker J, \& Westrup H, The English Language Teacher's Handbook: How to Teach Large Classes with Few Resources. London: Continuum, 2000.

[19] Newmann, Fred M, Student Engagement and Achievement in American Secondary Schools, New York: Teacher College Press, 1992.

[20] Harper, S. R., \& Quaye, S. J, "Beyond, Sameness, with Engagement and Outcomes for All: An Introduction. In S. R. Harper \& S. J. Quayle (Eds.)," Student Engagement in Higher Education Theoretical Perspectives and Practical Approaches for Diverse Populations pp. 1-16. New York: Routledge, 2009. https://doi.org/10.1080/03075079.2011.598505

[21] Trowler, V. Student Engagement Literature Review. The Higher Education Academy, 2010. https://doi.org/10.1037/0022-0663.85.4.571

[22] Gunuc, S. The Relationships Between Student Engagement and Their Academic Achievement. International Journal on New Trends in Education and Their Implications, vol. 5 (4), pp. 216 231, October 2014.

[23] Robinson, Carol, "Student Engagement: What Does This Mean in Practice in The Context of Higher Education Institutions?" Journal of Applied Research in Higher Education, vol. 4 (2). pp. 94-108, April 2012. http://dx.doi.org/10.1108/17581181211273039

[24] Morell, T, "What Enhances EFL Students' Participation In Lecture Discourse? Student, Lecturer And Discourse Perspectives," Journal of English for Academic Purposes, vol.6 (3), pp.222-237, 2007. https://doi.org/10.1016/j.jeap.2007.07.002

[25] Tehrani, Afsaneh Rahimi, \& Hossein Vahid Dastjerdi, "The Pedagogical Impact of Discourse Markers in the Lecture Genre: EFL Learners' Writings in Focus," Journal of Language Teaching and Research, Vol. 3, No. 3, pp. 423-429, May 2012. https://doi:10.4304/jltr.3.3.423-429

[26] Griffiths, R, "Speech Rate and NNS Comprehension: A Preliminary Study in TimeBenefit Analysis. Language Learning (A Journal of Research in Language Studies) vol. 40 (3), pp. 311 336, 1990. https://doi.org/10.1111/j.1467-1770.1990.tb00666.x

[27] McMahon, M. (1997). Social Constructivism and the World Wide Web-A Paradigm for Learning. In Ascilite 97 (pp. 1-6). Retrieved from https://www.researchgate.net/publication/243618245_Social_Constructivism_and_the_W orld_Wide_Web-A_Paradigm_for_Learning

[28] Bates, T., \& Poole, G. (2003). Effective Teaching With Technology In Higher Education: Foundations For Success. San Francisco: Jossey-Bass. https://eric.ed.gov/?id=ED498562

[29] Reading, C. (2008). Recognising and Measuring Engagement in ICT-Rich Learning Environments. Australian Computers in Education Conference.

[30] Fredricks, J. A., Blumenfeld, P. C., \& Paris, A. H, "School Engagement: Potential of the Concept, State of the Evidence," Source: Review of Educational Research, vol. 74 (1), pp. 59-109, 2004. http://www.jstor.org/stable/3516061

[31] Lane, E., \& Harris, S, "Research and Teaching: A New Tool for Measuring Student Behavioral Engagement in Large University Classes," Journal of College Science Teaching. volume 44 (6), pp. 83-91, July 2015. https://doi.org/10.2505/4/jcst15_044_06_83 
[32] Carpenter, J. P, "Digital Backchannels: Giving Every Student a Voice Opening a New Channel, Teaching with Mobile Tech, vol. 72, No. 8, pp. 54-58, May 2015.

[33] Du, H., Rosson, M. B., \& Carroll, J. M, "Communication Patterns For A Classroom Public Digital Backchannel," Proceedings of the 30th ACM International Conference on Design of Communication-SIGDOC '12, pp. 127-136, October 2012. https://doi.org/10.1145/2379057.2379081

[34] Krishnan, J., \& Poleon, E, "Digital Backchanneling: A Strategy For Maximizing Engagement During A Performance-Based Lesson On Shakespeare's Macbeth,” Teaching English with Technology, vol.13 (4), pp. 38-48, 2013. http://www.tewtjournal.org

[35] Harry, D., Gordon, E., \& Schmandt, C, "Setting the Stage for Interaction: A Tablet Application to Augment Group Discussion in a Seminar Class," In ACM conference on Computer Supported Cooperative Work, pp. 1071-1080, February 2012. https://doi.org/ $10.1145 / 2145204.2145364$

[36] Yates, K., Birks, M., Woods, C., \& Hitchins, M, “\#Learning: The Use of Back Channel Technology in Multi-Campus Nursing Education. Nurse Education Today, vol.35, pp. 6569, June 2015. https://doi.org/10.1016/j.nedt.2015.06.013

[37] Mozzon-McPherson, M., The Skills of Counseling: Language As A Pedagogictool in J. Mynard \& L. Carson (Eds.), Advising in language learning: Dialogue, tools and context (pp. 43-64), 2012, Harlow, UK: Pearson Education.

\section{Authors}

Siti Yulidhar Harunasari is a certified lecturer and technology enthusiast. She currently works as the Head of English Language Education Program of STKIP Kusuma Negara, A School of Education, in Jakarta, Indonesia. Her education background includes bachelors in Chinese and English, and a Master's and Doctorate of Language Education. She has also been the keynote speaker in many local and national-level seminars.

Nurhasanah Halim (nurhasanah_halim@stkipkusumanegara.ac.id) is a teacher educator at the English Language Education Program of STKIP Kusuma Negara, A School of Education, in Jakarta, Indonesia. She has a master degree from the Language Education.

Article submitted 2018-07-02. Resubmitted 2018-11-22. Final acceptance 2019-01-27. Final version published as submitted by the authors. 